\title{
IJTIHAD POLITIK KYAI: PERGESERAN OTORITAS KHR. ACH. FAWAID AS'AD SITUBONDO
}

\author{
Oleh: \\ Nawawi \& Wawan Juandi \\ Universitas Ibrahimy \\ nawawithabrani71@gmail.com \&wwnjuandi@gmail.com
}

\begin{abstract}
:
This study found that the relationship between santri and kyai is a pattern of emotional relations such as the feudal system. Kyai has three pillars. They are the mass base as a pattern of social structure, the ulama base as a leadership structure and the cultural base as a scientific basis. However, these three pillars have experienced a shift due to the kyai's entry into practical politics due to his political ijtihad. This shift places the authority of the kyai from a spiritual teacher (central position) to a politician (peripheral position). In this case, the kyai is still obeyed when he is in a central position as a spiritual teacher and not obeyed when his position is marginal as a politician. Of course, this becomes an authority dilemma as experienced by kyai Fawaid who is directly involved in practical politics. The involvement of kyai Fawaid in politics does not belong to the opportunist category but is a form of concern for carrying out the commands of ma'ruf nahi munkar in social transformation. Kyai Fawaid's political ijtihad was strongly influenced by the habituation of Islamic boarding schools based on fiqh. Habituation here is to create a political situation and condition (persistence life situation) through a process of internalization and habituation in accordance with the values of the pesantren, not to be carried away by the flow of political habituation which is always pragmatic and materialistic. The result of his Ijitihad that winning in politics by deception must be abandoned and losing in the right way must be maintained. Thus, the findings of this study can invalidate the theory from the results of research that has been carried out by Ernst Utrecht, Mochtar Naim, Daneli Lev, Justus van der Kroef, Arnold Brackman and Munir Mulkan, where they say that kyai or pesantren of Nahdlatul Ulama who participate politics are opportunists.
\end{abstract}

Keywords: Ijtihad, Politik Kyai, Pergeseran, Otoritas Kyai 


\section{A. Pendahuluan}

Selam ini politik kyai dan NU berorientasi pada akomoditif dalam rangka menegakkan nilai-nilai Islam dalam realitas politik. Pendekatan yang digunakan kyai NU dalam dunia politik lebih mengarah pada aspek substantif ketimbang radikal dan konfrontatif. Tentu pendekatan ini memiliki tujuan untuk membangun harmoni dan kemanusian dalam konteks berbangsa dan bernegara. Konsekuensinya, ada anggapan bahwa politik kyai dan NU bersifat oportunis. Yakni, sebuah motivasi yang dilakukan kyai dan NU dalam politik demi ptercapainya kedudukan dan material. Argumentasi mereka dapat dilihat NU bergabung dengan golongan nasionalis untuk melawan Masyumi dan mendukung kabinet parlementer, tetapi tetap mendukung untuk kembali ke UUD $1945 .^{1}$

Walupun politik NU bersifat akomodatif, tetapi masih yang ada yang menduh negatif. Memang sedikit peneliti kyai yang bersusah payah mengunjungi pesantren atau menghadiri pertemuan-pertemuan kyai. Tidak banyak dari mereka yang menemui dan menjalin hubungan dengan kyai dalam rangka memahami ideologi, struktur, dinamika internal, dan basis sosio-ekonomi para kyai. Pada umumnya mereka mencukupkan diri dengan memberikan gambaran yang bersifat umum tentang doktrin dan praktek tradisional kyai, sebelum mengajukan sebuah penafsiran tentang kelompok oportunis. Sangat jarang mereka keluar dari stereotif negatif tentang kyai, sehingga berdampak pada kedangkalan analisis hasil pnelitiannya. $^{2}$ Dengan kata lain, hasil penelitian mereka tidak dapat dipertanggungjawabakan secara ilmiah karena belum mendalam dalam penelitiannya.

Asumsi negatif tentang perilaku politik kyai NU di era Orde Lama, antara lain dikemukakan oleh Ernst Utrecht bahwa NU sebagai partai yang luar biasa oportunisnya. Mochtar Naim menandai kecenderungan NU untuk menjadi oportunis dalam kancah politik. Daneli Lev menulis bahwa oportunisme NU sudah dan pemimpin nasional NU sudah sangat keterlaluan. Justus van der Kroef juga menulis bahwa NU secara oportunistik selalu berpihak kepada yang menang. Arnold Brackman menggambarkan bahwa NU sebagai agen bebas yang sering beraliansi dengan pemberi tawaran lebih tinggi. Para kyai ini, siap bekerja sama dengan kelompok manapun, termasuk PKI, asalkan perasaan keagamaan

1 John Greg Fealy, Ulama and Politic in Indonesia A History of Nahdlatul Ulama, Disertasi (Australia: Monash University, 1998), 189.

2 Greg Fealy, "Kata Pengantar," dalam Ahmad Muhajir, Idham Chalid: Guru Politik Orang NU (Yogyakarta: Pustaka Pesantren, 2007), 8-9

$242 \mid$ JURNAL LISAN AL-HAL 
mereka tidak diganggu dan tuntutan finansialnya terpenuhi. ${ }^{3}$ Padahal, pada masa Orde Baru, posisi kyai dalam politik nasional terpinggirkan dan dicurigai pemerintah. Walaupun demikian, kyai NU tetap senantiasa berjuang dalam menentukan sikap politik sesuai dengan pandangan mereka. Misalnya, KH. Bisri Syamsuri disamping sebagai pengurus NU dan Ketua Mejelis Pertimbangan PPP telah berani mnegeluarkan fatwa politik bahwa umat Islam wajib memilih PPP. ${ }^{4}$

Berdasarkan uraian di atas, menarik untuk meneliti KHR. Fawaid As'ad selaku pengasuh pesantren besar di Situbondo Jawa Timur yang masuk dalam dunia politik praktis. Sebab, politik selalu identik dengan kekuasaan dan kayai sebagai aktor politik pasti memiliki kekuasaan. Kyai pesantren sering kali menjadi incaran para politisi untuk meraup suara dan dukungan politik. Karena itu, pada biasanya suara kyai pesantren menjadi obyek perebutan politisi baik partai politik Islam maupun partai politik nasionalis dengan tujuan untuk memperoleh vote getter.

\section{B. Diskursus Fiqh Politik Dalam Islam}

Syekh Naquib al-Attas, pendiri International Institute of Islamic Thought Civilization (ISTAC) di Malaysia, mengemukakan betapa dunia Islam mengalami kemunduran akibat adanya konfrontasi historis yang dikekalkan oleh kebudayaan dan peradaban Barat terhadap Islam. Bagi alAttas, dilema yang dihadapi umat Islam saat ini disebabkan oleh; pertama, kebingungan dan kekeliruan dalam pengetahuan kedua, hilangnya adab dalam umat dimana kedua hal tersebut mengakibatkan munculnya pemimpin yang tidak cakap untuk memimpin umat yang sah karena tidak memiliki standar moral, intelektual, dan spiritual yang tinggi sebagai acuan kepemimpinan Islam. ${ }^{5}$ Dale Eickelman dan ilmuwan politik James Piscatori menyimpulkan bahwa gambaran politik Islam di seluruh dunia dewasa ini adalah pertarungan terhadap penafsiran makna-makna Islam dan penguasaan lembaga-lembaga politik formal dan informal yang mendukung pemaknaan Islam tersebut". Pertarungan seperti ini melibatkan "objektivikasi" pengetahuan tentang Islam yang pada gilirannya memunculkan pluralisasi kekuasaan keagamaan. ${ }^{6}$

\footnotetext{
3 Greg Fealy, Ijtihad Politik Ulama: Sejarah NU 1952-1967 (Yogyakarta : LKiS, 2009), 4-7.

${ }^{4}$ Faisal Ismail, Ideologi Hegemoni dan Otoritas Agama Wacana Ketegangan Kreatif Islam dan Pancasila (Yogyakarta : Tiara Wacana, 1999), 234.

5 Naquib Al-Attas, Islam dan Sekularism (Bandung: Penerbit Pustaka, 1981), 43

6 Azyumardi Azra, "Kata Pengantar" dalam Idris Thaha, Demokrasi Religius \begin{tabular}{l|l} 
JURNAL LISAN AL-HAL & 243
\end{tabular}
} 
Al-Farabi melukiskan ilmu etika dan politik sebagai perluasan (highest manipestasion) dari metafisika yang tingkat tertingginya adalah pencapaian ilmu tentang Tuhan. ${ }^{7}$ Para pemikir politik Sunni berpadangan bahwa masalah kepemimpinan merupakan masalah keduniawian. Karena itu, kewajiban mengangkat pemimpin politik ditentukan oleh kesepakatan kaum Muslimin (ijma'), berdasarkan pertimbangan wahyu (agama). Penentuan pengganti Nabi diserahkan kepada kaum Muslimin, bukan ditentukan oleh wahyu. Sedangkan Syiah berpendapat bahwa penentuan kepemimpinan setelah wafatnya Nabi adalah ditentukan oleh wahyu yakni hadits Ghadir Khum yang mereka pahami bahwa Nabi Saw telah menunjuk Ali, menantu dan keponakannya sebagai pengganti Nabi. ${ }^{8}$

Pemerintahan yang bersih menjadi daya tawar tersendiri bagi terwujudnya masyarakat madan. Di satu sisi, pemerintahan yang bersih menjadi prasyarat akan tumbuhnya masyarakat madani yang sehat. Namun di sisi lain, pertumbuhan masyarakat madani akan menuntut performance pemerintahan yang bersih, efesien, efektif dan profesional. Dari aspek makna, demokrasi menjadi solutif dalam proses pemerintahan yang bersih dan masyarakat madani. ${ }^{9}$ Masyarakat madani merupakan tatanan masyarakat perkotaan yang kosmopolit dan tunduk di bawah aturan perundang-undangan. Kemudian pengertian masyarakat madani dapat disederhanakan menjadi tatanan masyarakat yang ditopang denagn pilar agama, peradaban dan cosmopolitan. ${ }^{10}$ Masyarakat madani terdiri dari berbagai warga beraneka warna, bakat dan potensi, maka karena itulah masyarakat madani dinamakan dengan masyarakat multi kuota (multi qouta society). ${ }^{11}$

Dalam konteks ini, makna yang terkandung pada konsep "politik" berkaitan dengan kekuasaaan, penggunaan kekuasaan dan cara

(Bandung: Mizan 2005), XVI.

7 Majid Fakhri, A History of Islamc Philosophy (New York: Columbia University Press, 1983), 7

8 Kamil, S, Pemikiran Politik Islam Tematik, Agama dan Negara (Yogyakarta: Kencana Predana Media Group, 2013), 11.

${ }^{9}$ Riyadi Santoso, Pemerintahan Yang Bersih dan Masyarakat Madani (Yogyakarta: Tiara Wacana, 1998), 19

10 Anwar Ibrahim ,"Islam dan Pembentukan Masyarakat Madani", dalam Aswab Mahasin (eds.), Ruh Islam dalam Budaya Bangsa: Wacana Antar Agama dan Bangs (Bandung: Mizan, 2000), 22.

11 H.A.R. Tilaar, Pendidikan Kebudayaan dan Masyarakat Madani Indonesia (Bandung: Remaja Rosda Karya, 1999), 159.

$244 \mid$ JURNAL LISAN AL-HAL 
pengelolaan pemerintahan suatu negara. ${ }^{12}$ Dalam ilmu fiqh ada satu bagian pokok kajian menegenai perpolitikan, yaitu Fiqh al-Siyasah. Fiqh Siyasah adalah ilmu tata negara, yang mengkaji tentang seluk-beluk kenegaraan untuk mewujudkan kemaslahatan umat manusia sesuai dengan syariat. ${ }^{13}$ Dalam hal ini, fiqh Siyasah memiliki kriteria,: pertama, institusi pemerintahan sebagai pengendali aktifitas pemerintahan. Kedua, masyarakat sebagai pihak yang diatur. Ketiga, kebijaksanaan dan hukum yang menjadi instrumen pengaturan masyarakat. Keempat, cita- cita ideal dan tujuan yang hendak dicapai. ${ }^{14}$ Ibnu Taimiyah, menegakkan agama sebagai tugas suci yang fungsinya amat besar untuk menegakkan keadilan memberanta kejahatan, memasyarakatkan tauhid dan mempersiapkan munculnya sebuah negara yang mengabdi kepada Allah. ${ }^{15}$

Secara aplikatif, Gabriel Almond dan J.S. Coleman mengemukakan dua fungsi utama politik, yaitu fungsi-fungsi masukan (input punctions) dan fungsi-fungsi keluaran (output punctions), Yang termasuk input punctions meliputi sosialisasi politik, rekruitmen politik, artikulasi kepentingan, agregasi kepentingan dan komunikasi politik; sementara kategori output punctions adalah pembuatan aturan-aturan, pelaksanaan aturan-aturan dan pengawasan atas terlaksanya aturan-aturan itu. ${ }^{16}$

\section{Hasil Penelitian Dan Diskusi Temuan}

\section{Sejarah Singkat KHR. Ach. Fawaid As'ad}

KHR. Achmad Fawaid As'ad merupakan putra KHR. As'ad Syamsul Arifin dengan Situbondo yang dilahirakan pada 17 Nopember 196. Ibunya, Nyai Zubaidah Fawaid memberi nama dengan Kamiluddin (orang yang sempurna agama). Namun, dikarenakan ada sesuatu dan lain hal, nama itu dirubah menjadi Ahmad fawaid oleh kakak sulungnya yang bernama Nyai Zainiyah As'ad. Seperti kelahiran abahnya, Fawaid kecil juga dibawa keliling ka'bah oleh ayahandanya. Ketika sekitar berumur 13 tahun Kyai Fawaid mempunyai hasrat yang sangat besar untuk mondok di pondok-pondok yang pernah di singgahi oleh sang ayahandanya, namun

27.

12 M. Amin Rais, Cakrawala Islam, antara Cita dan Fakta (Bandung: Mizan, 1996),

13 Ahmad Sukarja, "Fikih siyasah" dalam Taufik Abdullah (eds.), Ensiklopedi Tematis Dunia Islam, Ajaran, II (Jakarta: Ichtiar Baru Van Hoeve, 2002), 191

14 Sukarja, Ahmad, "Fikih Siyasah" dalam Taufik Abdullah (eds.), Ensiklopedi Tematis Dunia Islam, Ajaran, II .( Jakarta: Ichtiar Baru Van Hoeve, 2002), 193.

15 Ibn Taimiyah, Al-Siyasah al-Syariah (Kairo: Dar al-Kutub al-Arabi, t. th), 174.

16 Abd. Muin Salim, Konsepsi Kekuasaan Politik dalam al-Qur'an (Jakarta: Raja Grapindo Persada, 2002), 41-45 
apalah daya hasrat itu terhalang restu ayahandanya. Namun halangan itu bukan tanpa alasan, dari literatur yang ada diceritakan bahwa KHR As'ad Syamsul Arifin tidak memondokkan Kyai Fawaid karena tiga alasan yang diambil dari dauhnya KHR. As'ad Syamsul Arifin diantaranya: pertama , "sengkok ajege akhlakkah tang anak takok sampek cangkolang ka guru" (saya menjaga akhlak anak saya takut tidak sopan kepada gurunya). Karena ketika sedikit saja "cangkolang" maka dampaknya akan sangat besar terhadap perkembangan dia kedepan. Kedua, "Saya khawatir anak saya ikut-ikutan kepada faham-faham tidak tidak benar yang tengah berkembang di pondok dimana ia mau mondok". Ketiga, kalau hanya urusan ilmu, disini sudah ada pakarnya yang layak untuk dijadikan sebagai guru yaitu khofi (KH. Afifuddin Muhajir, M.Ag) Kyai As'ad mengatakan "pa abik jeriya ilmuna Khofi, cokop jeriya" (habiskan ilmunya Khofi, itu sudah cukup). ${ }^{17}$

Selanjutnya, pada hari sabtu tanggal 4 Agustus 1990 ayahanda KHR. As'ad Syamsul Arifin wafat dalam usia 95 tahun. Tongkat estafet kepengasuhan secara resmi beralih pada KHR. Ach. Fawaid As'ad. Usia beliau relatif sangat muda, yakni 22 tahun. Banyak tokoh yang meragukan kemampuan Kyai Fawaid muda, bahkan masyarakatpun pesimis. Terlebih apabila diukur dari dengan multi kapasitas yang dimiliki almarhum Kyai As'ad. Namun, keraguan itu lambat laun sirna, setelah melihat realita pondok pesantren yang semakin berkembang. Menjadi penerus Kyai As'ad bukan sesuatu yang mudah kerena harus melanjutkan perjuangan berupa pesantren yang tergolong besar dengan belasan ribu santri yang berasal dari berbagai daerah di Indonesia dan negara sekitar. Dalam mengemban amanat yang berat ini, tak lupa beliau melaksanakan umroh untuk bermunajat kepada Allah agar diberi kekuatan dalam melanjutkan kepemimpinan almarhum Kyai As'ad.

Dalam munajatnya, beliau mengadu kepada Allah, "Jika kiranya bermanfaat kepada pesantren, berilah kemampuan. Jika tidak, maka cabutlah umur hamba saat ini juga" sebagai pengasuh pesantren dan juga sebagai pengayom masyarakat, pengagum Rhoma Irama ini melangkah dengan penuh optimis dan akhirnya Kyai Fawaid memainkan perannya dengan paripurna. Tidak hanya dengan melakukan umroh, diawal mengasuh pesantre, bersilaturrahmi kepada Kyai sepuh dengan tujuan meminta do'a dan bimbingan selalu dilakukannya. Sebab bagi Kyai Fawaid, bukanlah pekerjaan yang mudah meneruskan apa yang menjadi tanggung

17 Pondok Pesantren S2 Sukorejo, Biografi 3 Masyayih Sukorejo (Situbondo: P2S3, t. th), 14-15

$246 \mid$ JURNAL LISAN AL-HAL 
jawab Kyai As'ad. Sampai-sampai beliau berdawuh "jangankan berkembang, bertahan saja sudah bagus".18 Selain itu, kyai Fawaid juga aktif dalam partai politik sebagaimana yang telah tercatat dalam sejarah perpolitikan bahwa keaktifan beliau dipanggung politik telah berhasil mewarnai dan mendobrak perjalanan perpolitikan umat manusia yang durjana dan tidak bermoral menjadi lebih bermartabat dan penuh dengan keadilan dan kebenaran. Hingga menjelang wafat (Jum'at 16 Rabi' atsTsani $1433 \mathrm{H}$ yang bertepatan pada tanggal 09 Maret 2012.

\section{Pergeseran Otoritas Kyai: Implementasi Amar Ma'ruf Nahi Munkar}

Dalam setting sosial Indonesia cepat berubah seperti sekarang ini seiring terbukanya akses pendidikan tinggi dan globalisasi. Hal ini melahirkan kesadaran baru terhadap persepsi kepemimpinan, yaitu dari kepemimpinan individual menuju kepemimpinan kolektif. Sikap masyarakat terhadap kepatuhan kyai dan penguasa juga tidak mudah untuk diukur secara pasti. Sebagian masyarakat masih memiliki kepatuhan terhadap kyai. Namun, berbeda dengan politik, otoritas kyai sudah mulai bergeser, dimana pergeseran otoritas kyai NU karena pemahaman masyarakat yang semakin kritis dalam merespon doktrin agama.

Hal ini dapat digambarkan juga sosok kyai Fawaid yang masuk dalam dunia politik praktis. Meskipun kyai Fawaid sebagai ketua PPP banyak meminta dukungan dan memberikan sumbangan kepada pesantren, tetapi tidak pernah bergeser untuk mendukung calon atau partai yang memiliki hubungan dengan NU. Seandainya mendukung partai tertentu dengan pertimbangan uang, niscaya kyai Fawaid tidak akan mendukung PPP atau kader NU yang lain. Sebab, secara financial banyak partai-partai atau calon pemimpin lain yang menawarkan harta yang lebih banyak, tetapi faktanya tidak demikian yang dipilihnya. ${ }^{19}$ Mengenai fitnah yang menerpa dirinya, Kyai Fawaid bercerita kepada masyarakat, sebagai berikut:

“... tuduhan-tuduhan bertambah ke saya, dikira saya menerima sumbangan dari pak Hamzah, ketua-ketua partai yang datang (ke Sukorejo) katanya diundang saya, bukan datang sendiri. Memang, Pak Hamzah datang bulan Syakban, nyumbang ke pesantren, Pak

18 Lebih detailnya baca Syamsul Arifin, "Kyai Fawaid As'ad: Kepribadian, Pemikiran dan Perilaku Politik, Jurnal Tanwirul Afkar, 2018.

${ }^{19}$ Wawancara, Syairozi, 16 Januari 2020 
Akbar bulan puasa datang ke pesantren, nyumbang untuk pesantren, Pak Amin Rais datang ke pesantren, (bliau juga) nyumbang ke pesantren, tapi saya, perjuangan saya, pengabdian saya, baik di NU, di partai politik, atau di pesantren, atau sebagai tokoh masyarakat atau saya sebagai khalifah yang ditunjuk sebagai penerus di pondok ini, pas mau ditukar dengan uang, dan jabatan dan kedudukan? Na'uzubillah-na'uzubillah. Saya mohon dijauhkan dari hal yang seperti itu, tidak! Saya tidak mau menukar (perjuangan dan pengabdian) dengan dunia. Kalau memang saya ingin menukar pesantren saya dengan uang, ingin menukar jabatan dengan uang, untuk apa saya mengajar sampean? Karena saya dipecat tidak sendirian, di belakang saya ada pendukung, ada gerbong yang dari kepengurusan cabang sampai ranting, belum lagi ditambah santri, alumni, dan masyarakat, dan tokoh-tokoh masyarakat yang sudah nyata-nyata sudah tahu bagaimana saya dizalimi, bagaimana difitnah, bagaimana saya diadu domba, dipecah belah. Tidak mungkin saya membiarkan pendukung-pendukung saya baik yang ada di dalam kepengurusan maupun panjenengan sekalian, lalu Golput. Atau asal milih partai yang tidak jelas misi dan visi perjuangannya, khususnya untuk kepentingan jam'iyah Nahdatul Ulama, kepentingan Islam ahlusunnah waljama'ah. kalau saya tidak memikirkan itu, saya tidak perlu rame-rame yang penting saya kenyang sendiri, yang penting uang banyak, gak perlu bicara-bicara, diam, tapi saya tidak..."20

Keluarnya Kyai Fawaid dari PKB ke PPP juga mendapat dukungan dari PBNU. Sebab, langkah tersebut merupakan logis yang didasarkan pada sikap bertanggungjawab, berakhlakul karimah, apalagi lebih disebabkan perlakuan tidak adil. Pernyataan ini disampaikan oleh Said Aqil Siradj di hadapan 50 ribuan nahdiyyin yang memadati lapangan desa Sumberejo, Banyuputih, Situbondo, pada acara Peringatan Tahun Baru Islam, 1 Muharram 1425 Hijriyah. ${ }^{21}$ Namun, di sisi lain banyak terjadi penghinaan pada kyai fawaid baik secara pribadi maupun pesanternya. Bahkan banyak terjadi perselisihan di arus bawah, seperti carok antara pendukung PPP dan PKB, tentangga yang satu dengan lain dan suami istri

20 Dokumen Pesantren Salafiyah Syafi'iayah, Ceramah KH. Fawaid dengan Alumni Santri Sukorejo Situbondo di Aula Sukorejo Tahun 2004.

${ }^{21}$ KHR. Fawaid, "Tidak Mau Menukar Pesantren dengan Uang," Harian Bangsa Edisi 10, Januari 2004

248 JURNAL LISAN AL-HAL 
bercerai karena perbedaan pilihan PPP dan PKB. ${ }^{22}$

Kecenderungan kyai Fawaid mendukung PPP memperlihatkan sebagai kyai politisi yang memiliki basis dukungan yang sangat besar. PPP dianggap sebagai salah satu parati Islam yang menjadi warisan ulama NU terdahulu apalagi KH. Maimoen Zubair, Jawa Tengan tetap konsisten di PPP hingga akhir hayatnya. ${ }^{23}$ Tentu, komunitas ini berkaitan dengan elit keagamaan dalam istilah Masdar Hilmy dapat memberikan kontribusi signifikan dalam mensukseskan misi partai politik. Padahal polarasi politik kyai berpindah dari PKB ke PPP akan melahirkan persoalan baru dengan sikap kaum santri yang sebelumnya dikenal memiliki respektasi dan ketaatan tinggi pada kyai. Kembali pada pokok persoalan, dalam wacana politik peran kyai sangat strategis tetapi juga dilematis. ${ }^{24}$ Sebagai elit politik, kyai wajib mengarahkan umat pada partai tertentu sebagai warga negara yang memiliki hak pilih. Dari aspek elit agama, kyai memiliki tanggung jawab moral dalam membawa nilai-nilai agama, berupa amar ma'ruf nahi munkar sebagai visi agama.

Pudarnya otoritas kyai ini disebabkan oleh keterlibatannya yang terlalu jauh memasuki wilayah politik praktis. Padahal perilaku politik dirumuskan sebagai kegiatan yang berkenaan dengan proses pembuatan dan keputusan politik. Mislanya, kyai Fawaid pada waktu turba ke lapangan untuk mensosialilasikan PPP pada alumni dan masyarakat dapat penolakan dan demontrasi, seperti yang terjadi di kepulauan Kangean Sumenep yang menjadi basis massa pondok Sukorejo. ${ }^{25}$ Perilaku politik juga termasuk kegiatan masyarakat proses memperoleh kekuasaan, mempertahankan kekuasaan, dan mengembangkan kekuasaan. Dengan rumusan lain perilaku politik adalah segala perilaku manusia baik secara individual maupun komunitas yang berkaitan dengan proses pembuatan kebijakan, konflik, kebaikan bersama, dan kekuasaan. ${ }^{26}$ Perbedaan afiliasi politik kyai melahirkan asumsi bervariasi dari komponen masyarakat, dimana sebelumnya kyai sebagai dinggap opinion leader dalam mengambil kepeutusan yang harus diikutinya.

Menurut Sudijono Sastroadmodjo bahwa perilaku politik berkenaan dengan tujuan suatu masyarakat, kebijakan untuk mencapai suatu tujuan, serta sistem kekuasaan yang memungkinkan adanya suatu

22 Wawancara, Muhyiddin Khatib, 12 Maret 2020

${ }^{23}$ Wawancara, KH. Jaiz Badri Masduqi, 13 Januari 2020.

${ }^{24}$ John Greg Fealy, Ulama and Politic, 277.

25 Wawancara, Badrul Munir, 12 Pebruari 2020.

26 Ramlan Surbakti, Memahami Ilmu Politik (Jakarta. Gramedia Widya Sarana, 1992), 17 
otoritas untuk mengatur kehidupan masyarakat ke arah pencapaian tujuan tersebut.27 Kyai Fawaid menjadi tim sukses diniatkan untuk perjuangan NU, maka sangat wajar kalau semua dana kampanye dihabiskan untuk biaya memenangkan calon yang diusung. Bahkan, tidak jarang beliau mengeluarkan pribadi untuk biaya operasional tim sukses yang lain. Tetapi kalau tim sukses 'kacangan' yang niatnya sebagai tim sukses hanyalah mencari uang, maka setiap ada dana kampanye akan dihabiskan untuk kepentingan dirinya. Parahnya lagi, dia akan berpindah dari satu partai ke partai yang lainnya tergantung besar dan kecilnya dana yang diberikan. ${ }^{28}$ Sikap seperti ini yang tidak disukainya, sebagaimana pernyataan Kyai Fawaid, sebagai berikut:

“... Tidak, saya mencari rizki yang lain, usaha yang lain. Walaupun saya dapat untuk kepentingan tim sukses yang dari IKSASS dicatat, dipertanggungjawabkan. Silahkan kamu kalau saya dianggap, 'iya Kyai, anu-anu, lihat! Apa yang diberikan kepada saya, dicatat dan dipertenggungjawabkan, dilaporkan, serupiah aja saya laporkan; untuk ini, untuk itu, saya laporkan. Saya tidak mau nanti (uang) tidak ketemu wujudnya. Ada tim sukses-tim sukses, pokoknya lebih banyak, dikasih sejuta, dua ratus yang dipakek, sisanya diambil sendiri. Semuanya saya ada pertanggungjawabannya. Silahkan dicek ke Muhyiddin. Muhyiddin mau menggunakan uang, ditakar dengan saya, segini dulu, segitu dulu, saya gitukan. Biar kamu tahu, saya tidak mau dibilang gitu (korupsi). Semuanya dipertanggung jawabkan, kenapa? Saya takut..."29

Menurut Snouck Hurgronje dikutip oleh Azzumardy Azra, Islam kultural agaknya hampir identik dengan 'Islam Ibadah', atau 'Islam masjid', yang tidak ada hubunganya dengan politik. Islam Struktural yang diwujudkan melalui upaya perubahan kesadaran tingkah laku umat tanpa keterlibatan Negara dan tanpa perubahan sistem nasional menjadi sistem Islami. ${ }^{30}$ Dalam konteks ini, kyai Fawaid sebagai ketua partai melakukan pembenahan di dalam proses penyeleksian calon anggota dewan yang akan diusung oleh partai. Anggota dewan yang diberangkatkan dari partai yang dipimpinnya harus melalui tes yang benar-benar selektif, tidak

${ }^{27}$ Sudijono Sastroatmodjo, Perilaku Politik IKIP Semarang (Semarang: Semarang Press, 1995), 43.

${ }^{28}$ Wawancara, Zaini Ahsin, 11 Maret 2020

${ }^{29}$ Dokumen ceramah KH. Fawaid pada Reuni Alumni 2008.

${ }^{30}$ Azyumardi Azra, Kedatangan dan Penyebaran Islam di Asia Tenggara (Bandung: PT. Remaja Rosdakarya, 2000), xxiii

$250 \mid$ JURNAL LISAN AL-HAL 
tebang pilih. Penempatan kader partai sebagai calon legislatif haruslah orang yang benar-benar memiliki kemampuan di bidangnya. Hal ini sangat penting, karena kalau sampai yang menjadi anggota dewan adalah yang tidak memiliki kemampuan, maka kasihan hak-hak masyarakat akan terbengkalai. ${ }^{31}$ Dalam persoalan ini, Kyai menyampaikan kepada masyarakat melalui pidatonya:

"Dan, saya ingin membenahi bagaimana caranya mengangkat anggota dewan. Saya ingin, mengangkat anggota dewan melalui tes, kalau seandainya berjalan normal, neka (ini) keinginan saya, karena apa? Saya ingin anggota dewan yang akan dudukbenar-benar tahu, paham, dan mengerti apa yang menjadi tugasnya. Kadang-kadang kita sering kali asal memilih orang, tapi orang itu bukannya hanya persoalan dikenal atau tidak dikenal, bukan persoalan karena orang itu punya aktifitas di masyarakat. Tapi nyatanya setelah didudukkan, gak paham apa yang harus dilakukan, yang dilakukan pas tidak paham, ini kan percuma. Apa fungsi dari DPR, fungsi dari legislatif itu apa? Apa tugas-tugasnya? Ketika diajak membahas undang-undang, tidak mengerti tidak paham, ini kan berat namanya. Tidak hanya sekedar untuk menampung aspirasi masyarakat, tetapi di situ (bisa) menggodok aturan-aturan, UU peraturan daerah, termasuk memperjuangkan nasib masyarakat di daerah itu sendiri. Bagaimana bisa menumbuh-kembangkan ekonomi masyarakat, mengangkat harkat dan martabat masyarakat dari masyarakat yang lemah menjadi masyarakat yang mampu, masyarakat yang buta huruf menjadi masyarakat yang bisa membaca, mengangkat dan memajukan pendidikan, sebenarnya banyaklah tanggung jawabnya. Sementara, saya melihat banyak masyarakat banyak dikecewakan oleh kerjanya pengurus dan kerjanya dewan-dewan, ini tujuan saya, tidak ada yang lain..."32

Kepada para calon legislatif dari partai PPP, Kyai Fawaid menyampaikan agar mereka semua memperbaiki niat. Tidak boleh sedikitpun terselip ada keinginan untuk mencari uang, atau ingin dihormati orang lantaran menjaadi pemimpin. Kalau ini yang menjadi niat dan tujuan utamanya, dapat dipastikan ketika menjabat tidak akan memikirkan kesejahteraan rakyat. Pasti yang akan dipikirkan hanyalah bagaimana bisa mendapatkan uang sebanyak-banyaknya. Sebagaimana disebutkan dalam penjelasan sebelumnya bahwa beliau sangat

31 Wawancara, Arifin Muhajir, 18 Januari 2020

32 Wawancara, Zeineye, 18 Januari 2020 
menekankan agar calon pemimpin berniat sebagai pejabat untuk beribadah kepada Allah SWT, niat berjuang untuk jam'iyah Nahdatul Ulama (NU), masyarakat, dan untuk pesantren. ${ }^{33}$

Kyai Fawaid berpesan agar usaha dan pekerjaan yang sudah ditekuni sebelum menjadi anggota dewan agar tetap ditekuni, jangan sampai lantaran menjadi dewan kemudian pekerjaan yang sudah dikerjakan sebelumnya ditinggalkan. Dalam hal ini beliau memberikan nasihat:

“... Setelah saya jadi ketua partai, saya bilang ke para pengurus PAC PPP, ranting PPP, DPR, saya kumpulkan, saya bilang sama mereka semua, karena saya ketua partai, kalau kamu duduk di dewan, awas niatnya perbaiki, jangan sampai niat cari kasab (uang) di sana, kalau kamu niat cari uang, tak usah jadi DPR. Tapi niat beribadah, berjuang untuk Jam'iyah Nahdatul Ulama, masyarakat, untuk pesantren. Kamu jangan membuang pekerjaan yang jelas-jelas kamu kerjakan sekarang. Yang tani, berdagang, jangan berhenti bertani dan berdagang hanya gara-gara menjadi DPR. Kalau sudah tidak jadi DPR, mau kerja apa? Pas mau mengandalkan gajinya DPR, pas tidak memikirkan rakyatnya. Ini yang saya pesan, makanya santri dan alumni juga kayak gitu, jangan sampai semata-mata mencari uang, kalau itu yang dipikirkan, saya yakin kamu tidak mungkin memikirkan rakyat dan pendukungnya. Jangan heran kalau kemudian masyarakat bilang, 'kalau sudah jadi dewan lupa ke masyarakat'..."

Sikap keluarnya Kyai Fawaid dari PKB ke PPP sebagai bentuk protes terhadap kelompok dominan Situbondo yang berbasis masyarakat paternalistik-religius. Dalam teori politik, sikap kyai tersebut sebagai bentuk kritk hegemomi (counters-hegemoni). Hal ini merupakan resistensi terhadap monopoli kekuasaan yang meliputi level politik dan pemerintahan. Konsekuensinya, pada saat ini suara warga NU Situbondo dan segala komponen masyarakata terpecah belah menjadi beberapa pilihan partai politik baik nasionalis maupun religius. ${ }^{34}$ Perpecahan internal dapat respond dan dukungan kyai yang memiliki relasi dengan kyai induk. Hal ini merupakan sistem budaya yang dapat mengantarkan pelembagaan struktur budaya yanf faktual. Pelembagaan ini akan menempatakan posisi sentral pedesaan dalam kehidupan sosial dengan mengakar dan kuat di arus bawah. Jadi, Kyai sebagai komunitas elite yang

${ }^{33}$ Wawancara, Maskuri Ismail 12 Januari 2020

${ }^{34}$ Wawancara, Muhammad Isfironi, 15 Januari 2020

$252 \mid$ JURNAL LISAN AL-HAL 
memiliki kekuatan simbolik yang meliputi sosio-kultural, sosio-politik, dan sosio-ekonomi. ${ }^{35}$

Kebesaran PPP yang berasal dari suara nol pasca reformasi menjadi 11 kursi di Situbondo merupakan efektivitas kepemimpinan Kyai Fawaid. Jika ditinjau dari teori kepemimpinan paling tidak memiliki dua pendekatan. Pertama, power-pengaruh dan pendekatan sifat (trait theory). Keefektifan kepemimpinan berdasarkan pendekatan yang pertama sangat ditentukan oleh besarnya power yang dimiliki kyai. Power seorang kyai merupakan kekuatan yang diakui oleh pengikutnya menjadi sesuatu yang dapat mempengaruhi mereka. Power ini dapat berupa kedalaman ilmu kyai dalam agama dan otoritas yang dimiliki kyai terhadap pesantrennya. Sedangkan pendekatan sifat sebagai pendekatan karismatik yang dimiliki kyai, seperti sorotan mata, penampilan, ucapan, intonasi suara kyai. Kedua pendekatan ini jelas melekat dalam pribadai kyai Fawaid, sehingga dapat membesarkan PPP. Karena itu, perolehan PPP di Kabupaten Situbondo cukup signifikan hingga sekarang ini, sekalipun kyai Fawaid telah meninggal dunia. Hal ini berangkat dari kewibawan kyai Fawaid dengan arus dukungan santri dan alumni yang merata di seluruh Indonesia.

Dengan demikian, hubungan santri dan kyai merupakan pola hubungan emosional sebagaimana terjadi pada sistem feodal tanpa struktur dan tingkatan politis. Dalam kehidupan sosial, memang kyai dan keluarganya menduduki posisi yang tinggi daripada umumnya kaum santri. Menurut Irsan sebagaimana dinuki oleh Kacung Marijan bahwa tradisi kayai bertumpu pada tiga pilar utama, ${ }^{36}$ yaitu: basis massa sebagai pola struktur sosialnya, basis ulama sebagai struktur kepemimpinan dan basis tradisi sebagai sistem budaya yang dapat merekatkan visi keilmuan dan etika keislaman yang menjadi kekuatan pedomana masyarakat.

Dengan demikian, relasi kyai dan santri dalam dunia politik telah mengalami pergeseran pemahaman berupa kesadaran baru bahwa kyai memperoleh posisi baru dalam aspek fungsi. Artinya, semakin masyarakat rasional akan semakin menempatkan dirinya dalam mindset diferensiasi struktur fungsi yang khusus. Dalam teori pusat-pinggiran, logis adanya pemahaman masyarakat bahwa kayai pusat yang identik guru spiritual bergeser menjadi kayi pinggiran sebagai politisi. Karena

35 Zamakhsyari Dhofier, Tradisi Pesantren (Jakarta: LP3ES, 1982), 56; Faruk, "Harga Sebuah Kepekaan dan Suara Lain", dalam Pradjarta Dirdjosanjoto, Memelihara Umat: Kyai Pesantren-Kyai Langgar di Jawa (Yogyakarta : LKiS, 1999), xxvi 28.

${ }^{36}$ Kacung Marijan, Quo Vadis NU setelah Khittah 1926 (Surabaya: Erlangga, 1992), 
itu, tidak heran jika adanya pergeseran pemahaman masyarakat dari aspek kepatuhan ketika posisi kayai menjadi politisi, padahal sebelum menjadi politisi, kayai sangat dihormati dan segala tindakannya menjadi pedomana msyarakat. Dalam hal ini, posisi kyai tetap ditaati ketika kyai berada dalam posisi pusat sebagai guru spiritual dan tidak ditaati ketika posisinya berubah menjadi pinggiran. Dengan demikian, setiap kyai yang memasuki dunia politik, maka secara otomatis kyai telah merubah posisinya menjadi politisi. Jadi, posisi kyai tergantung pada posisinya jika masuk dalam dunia politik, maka dianggap oleh masyarakat sebagai manusia profan yang tidak wajib dipatuhi dan jika tidak masuk dalam dunia politik, maka dianggap sebagai manusia sakral yang wajib dihormati.

\section{Ijtihad Politik Praktis Kyai: Pengaruh Habituasi Pesantren}

Peran kyai Fawaid dalam politik praktis telah memberi pendidikan, perbaikan lingkungan, menjalin kegotong royongan dan pembinaan spirtual. Gerakan ini membuat hubungan antara kyai dengan masyarakat lebih dekat dan intim. Kyai memliki santri yang telah meyebar di tengah masyarakat bawah. Kyai dan santri merupakan bagian kelompok masyarakat Islam yang memiliki kesadaran keislaman yang lebih utuh ketimbang kelompok abangan dan priyayi. Komunitas santri sendiri merupakan produk kyai melalui pesantren. ${ }^{37}$ Akibatanya, santri di tengah masyarakat akan membentuk sistem budaya yang dapat dikendalikan secara politik. Dalam hal ini, kyai memiliki cita-cita politik sesuai dengan janji Allah Swt dalam al-Qur'an . Janji semacam ini diberikan oleh Allah Swt kepada orang-orang yang beriman dan beramal saleh, berupa tercapainya sistem politik dan hukum Islam diberlakukan dalam masyarakat. Cita-cita politik ini tercakup slogan al-Qur'an, yaitu "baldah thayibah wa rabb ghafur", yang artinya negara sejahtera dan sentosa. Cita-cita ini merupakan ideologi Islami sebagi bentuk nilai-nilai yang harus terwujud secara ril, sehingga menjadi instrumen khalifah sebagi aktualisasi kodrat manusia dalam membangun kemakmuran. ${ }^{38}$

Kyai Fawaid sebagai figur ulama dan pengasuh pesantren memiliki kekuatan yang signifikan karena memiliki masyarakat basis grass root yang kuat, sebagaimana di bawah ini:

37 Abdul Munir Mulkhan, Runtuhnya Mitos Politik santri (Yogyakarta: Rinneka SIPRESS, 1992), 1.

38 Abdul Mu'in Salim, Konsepsi Kekuasaan Politik Dalam Al-Qur'an (Jakarta; PT. Raja Grafindo Persada, 2002), 298.

$254 \mid$ JURNAL LISAN AL-HAL 
"Aktifitas KH.Fawaid dalam pentas politik praktis tak dapat dilihat sepintas lalu. Ia harus dilihat dari kacamata holistis. Keterlibatan aktif beliau tidak bisa disamakan dengan peran para kyai pada umumnya yang dapat dilihat dari satu faktor saja (kyai sebagai tokoh Agama), melainkan mempunyai banyak wajah (multy interpretations) yang mencerminkan kompleksitas atau keragaman cara pandang dalam berpolitik. Tentu, tidak semua kyai memiliki faktor yang demikian ini. Dengan kemampuannya yang baik, beliau dapat menciptakan kondisi politik yang kondusif: perannya sangat menentukan dalam menciptakan rakyat yang partisipatif. Dengan Kharisma yang kyai miliki, kyai mampu menggerakkan kesadaran masyarakat dalam menentukan pilihan. Pola hubungan kyai dengan santri, alumni, wali santri, dan simpatisan yang sangat erat, merupakan faktor penting dan berpengaruh dalam menentukan pilihan politik. Kyai sebagai elit lokal mempunyai karakteristik tersendiri dalam memberikan dukungan. Kyai dengan massa yang sangat hormat kepadanya mampu mendorong atau mendulang suara untuk kemenangan calon yang didukung. Kyai dengan kharismanya mampu memobilisasi massa dalam rangka penggalangan dukungan untuk suatu parpol, misalnya. Ketika Kyai masuk dalam sistem politik melalui parpol. Secara otomatis kyai menjadi bagian tim sukses atau juru kampanye calon yang didukung oleh parpol yang bersangkutan. Bermodal basis massa dan karisma, kyai mampu memainkan peran penting dalam suksesi pemilukada atau pilpres." 39

Paparan di atas logis karena masyarakat bawah adalah suatu kesatuan hukum dimana bertempat tinggal suatu masyarakat yang memiliki solidaritas. Apalagi masayarakat memiliki potensi saling mempengaruhi dalam sebuah sistem dalam proses merekonstruksi tradisi. Kyai memiliki dari dua tradisi, yaitu tradisi pesantren sebagai basis kultural dan tradisi pesantren sebagai mediator antara kepentingan partai politik dengan para pendukunngnya. Tradisi yang kedua ini menempatkan posisi politik kyai menjadi signifikan untuk diperebutkan partai politik dalam rangka memperoleh dukungan suara. Tradisi pesantren merupakan bentuk sistem sosial yang tumbuh di lingkungan pesantren melalui sistem kekerabatan yang telah dibangun kyai. Sistem kekerabatan yang dikembangkan kyai dengan landasan yang kuat melalui hubungan kekerabatan geneologi sosial kyai, jaringan aliansi perkawinan, geneologi

39 Ach. Muhyiddin Khatib dan Doni Ekasaputra, Ijtihad Politik KHR. Ach. Fawaid As'ad (Situbondo: Ibrahimy Press, 2014), 87-88. 
intelektual, dan aspek hubungan kyai dengan santri yang tidak hanya di batasi pada lingkungan pesantren dan persoalan keagaman saja tetapi bisa keluar dari lingkungan pesantren. Karena itu menurut survei, PPP selalu memperoleh suara signifikan di setiap tempat basis alumni dan santri Sukorejo.

Kyai yang terlibat politik praktis telah mengalami dilematis antara elit agama dan elit partai. Di astu sisi kyai sebagai penafsir ajaran agama dan pengasuh pesantern harus menjadi pedoman masyarakat. Dalam satu sisi, kyai juga memiliki tanggung jawab moral untuk berperan dalam konteks negara untuk melindungi masyarakat dari kewenagna-wenagan penguasa. Dalam hal ini, dua peran yang ada di pondak kyai sering menimbulkan benturan kepentingan. Ketika hubungan kyai denag penguasa harmonis, maka kyai kyai tidak ikut intervensi memperjuangkan kepentingan masyarakat akibatanya kayai akan ditinggalkan oleh masyarakat dan santrinya dalam kehidupan masyarakat. Implikanya kyai akan kehilangan otoritas sebagai elit agama jika dimenej dengan baik, maka kyai akan kehilangan daya tawar dalam ruang pemerintah sekaigus masyarakat. ${ }^{40}$ Memang secara formal, kayai bukan pejabat pemerintah yang harus ditaati, tetapi dalam aspek status sosial selalu dihormati dan taati ketimbang pejabat pemerintah. ${ }^{41}$ Inilah merupakan kekuatan kultural kyai yang masih eksis di tengah masyarakat, terutama kultul paternalistik-religius, seperti yang terjadi di Jawa Timur.

Pergeseran otoritas kyai Fawaid mesuk dunia politik praktis adalah berangkat dari komitmen pada pendiriannya bahwa politik tidak bisa menghalalkan segala cara. Baginya, di sinilah peran penting relasi agamapolitik. Boleh saja menggunakan strategi, tetapi jangan sampai meghalangi dan memperdaya orang menggunakan praktik atau strategi yang tidak halal. Pedoman ini sebenarnya dari nilai-nilai pesatren yang sangat teguh memegang syari'ah. Di saat "wabah" money politic menjalar di mana-mana, kyai Fawaid melarang keras melakukan praktik money politic. "Jangan menggunakan money politics, moral lebih didahulukan," seru beliau. Keuangan partai tidak boleh digunakan untuk money politic, tetapi untuk cost (biaya) politik. ${ }^{42}$ Yakni, komitmen kyai Fawaid ingin membangun politik yang bermoral dimana bnayak terjadi penyimpangan yang

40 Imam Suprayago, Kyai dan Politik di Pedesaan: Suatu Kajian tentang Variasi dan bentuk Keterlibatan Politik Kyai, Desertasi ( Surabaya: Universitas Airlangga. 1997), 21.

${ }^{41}$ Hiroko Horikoshi, Kyai dan Perubahan Sosial (Jakarta: P3M, 1987), 193.

42 Wawancara, Mahmudi Bajuri, 16 Januari 2020

256 JURNAL LISAN AL-HAL 
dilakukan oleh para elit plotik di Indonesia. Menurut Ibnu Khaldun, sebagaimana dinukil Rahman Zainuddin bahwa jatuhnya suatu bangsa adalah karena para elit hidup bermewah-mewah (mutra fiha) sehingga mencelakakan masyarakatnya. Untuk hidup bermewah-mewah, mereka melakukan korupsi, eksploitasi berlebih-lebihan terhadap sumber-sumber alam dan kemanusiaan. ${ }^{43}$

Dalam konteks varian kelompok priyayi sebagaimana istilah Clifford Geertz digunakan sebagai istilah orang yang memiliki tingkat sosial yang lebih tinggi atau sering disebut kaum bangsawan. Dalam realita, ada priyayi yang santri dan ada pula yang abangan, bahkan ada pula yang nonmuslim. Dalam dinamika sosial, sering ditemukan pola-pola konflik antara ketiga golongan tersebut dalam beberapa hal, yakni konflik idiologi, konflik kelas, dan konflik politik. Bahkan konflik terjadi dalam internal kaum santri dalam masalah politik, yaitu PKB. Keterlibatan aktif Kyai Fawaid di partai politik telah mengisyaratkan kepada kita bahwa jangan sampai karena beda baju partai, kita menjadi terpecah-pecah dan tercabikcabik. Sikap ini yang tidak ditemukan pada diri pribadi para politisi kita saat ini, baik di tingkat Lurah maupun Pusat. Partai dijadikan ajang untuk memusuhi orang lain, menjelek-jelekkan, memfitnah, mengadu-domba, dan semacamnya. Ironisnya, yang melakukan ini sebagian besarnya adalah tokoh masyarakat. Perbedaan partai tidak dijadikan sebagai sarana untuk bermusuhan. Hal ini dibuktikan saat beliau di PPP. Gus Dur tetap bersedia datang ke Sukorejo untuk bersilaturrahmi dengan Kyai Fawaid. Sebaliknya, kyai Fawaid juga datang menghadiri undangan Gus Dur ketika diundang acara walimah anak Gus Dur. Pada saat Gus Dur Wafat, beliau berada di barisan terdepan dalam upacra pemakamannya. Tentu saja ini merupakan pelajaran politik yang sangat berharga. ${ }^{44}$

Dalam konteks ini, pada dasarnya kyai merupakan penunjuk jalan politik benar-salah dan hitam putih bukan politik menang-kalah atau abuabu. Tugas kyai adalah penerang antara yang salah dan yang benar, bukan yang menang diperjuangkan walau harus hitam yang dilewati. Peran kyai mampu merekonstruksi bahwa dunia politik itu putih dan yang hitam harus dienyahkan dari dunia politik. Masyarakat mempunyai penilaian tersendiri atas status rangkap yang dimiliki kyai. Kyai independen lebih mereka hormati dari pada kyai yang berafiliasi pada kekuasaan Negara.

43 A. Rahman Zainuddin, "Ilmu Sejarah, Sosial dan Politik" dalam Taufik Abdullah (eds.), Ensiklopedi Tematis Dunia Islam, Pemikiran dan Peradaban (Yogyakarta: LkiS, 1999), 269-270.

${ }^{44}$ Wawancara, Maskuri Ismail, 15 Januari 2020 
Dalam persoalan ini, Kyai Fawaid dengan gamblang mengatakan:

"Saya mendukung Ibu Chafifah bukan karena semata-mata Ibu Chafifah, tetapi karena NU-nya. Dulu juga seperti itu, saya mendukung KH. Hasyim Muzadi, karena tahu kualitas dan kemampuannya KH. Hasyim Muzadi. Mana yang lebih manfaat walaupun ada NU-nya, figur, tokoh, kemampuan, peluang besar untuk NU, untuk kepentingan misi perjuangan kita. Meskipun dulu ada Hamzah Has yang nyalon presiden, tetapi karena ada tokoh NU yang jelas komitmennya. Apalagi sekarang gubernur, pertaruhannya adalah NU. Untuk alumni, pertaruhannya adalah Salafiyah Syafi'iyah. Jadi, loyalitas atau tidak akan ketemu. Komitmen melaksanakan amanatnya al-marhum atau tidak berarti kamu harus memenagkan Ibu Khofifah. All out berjuang ikhlas lillahi ta'ala. Bukan berjuang untuk baju, beras, dan uang..." 45

Apabila sikap politik kyai Fawaid dikaitakan dengan cita-cita luhur terbentuknya negara kesatuan republik Indonesia, maka sebenarnaya memiliki landasan ideologis nasionalis, sebagaimana terpateri pada alinea keempat dari pembukaan Undang-undanga Dasar Negara Republik Indonesia tahun 1945, yakni “...untuk melindungi segenap bangsa Indonesia dan seluruh tumpah darah Indonesia, dan untuik memajukan kesejahteraan umum, mencerdaskan kehidupan bangsa, dan ikut melaksanakan ketertiban dunia yang berdasarkan kemerdekaan, perdamaian abadi dan keadilan sosial.... ${ }^{46}$ maka sesungguhnya bisa diklaim bahwa dasar sikap politik kyai Fawaid tidak pernah padam sama sekali.

Dalam hal ini, keterlibatan kyai Fawaid dalam pollitik praktis tidak termasuk sikap oportunis, sebagaimana dikatakan oleh Munir Mulkan bahwa pada umumunya sikap oportunis NU di era Orde Baru sejak dulu menggunakan pendekatan fikih sebagai upaya legalisasi religi sesuai dengan rumusan teologi terhadap realitas objektif kehidupan sosial politik. Berdasarkan hal itu, sikap dan perilaku politik NU dapat dengan segera berubah drastis. Misalnya, jika dalam pemilu 1982 dan sebelumnya NU berfatwa bahwa wajib hukumnya bagi pemeluk agama Islam untuk memilih partai Islam, maka dalam pemilu 1987, NU mengeluarkan fatwa yang sama sekali berbeda yaitu mewajibkan anggotanya untuk memilih

45 Muhyiddin Khatib dan Doni Ekasputra, Ijtihad, 92

${ }^{46}$ Lembaga Ketahanan RI, Nilai-nilai Kebangsaan yang Bersumber dari UUD NRI Tahun 1945 (Jakarta: Lembaga Ketahanan Nasional Republik Indonesia, 2017), viii.

$258 \mid$ JURNAL LISAN AL-HAL 
Golkar. ${ }^{47}$ Salah satu kyai NU yang dianggap oportunis adalah KH Idham Chalid. 48 Jadi, perilaku politik kyai Fawaid tidak termasuk kategori oportunis tetapi bentuk kepedulian sosial untuk membangun politik bermoral dan bermartabat. Hal ini dapat dibuktikan ketika Ismunarso diusung dari PPP menjadi Bupati Situbondo ketika melakukan KKN pada akhirnya diturunkan sendiri oleh kyai Fawaid dengan memblokade jalan raya Pantura di Desa Sumberajo Kecamatan Banyuputih Kabupaten Situbondo selama 30 jam yang berimplikasi terjadinya macet total Banyuwangi-Surabaya. Tuntutan kyai yang ditujukan kepada SBY agar menurunkan Ismunarso sebagai bupati Situbondo. ${ }^{49}$

Dengan demikian, keterlibatan kyai Fawaid dalam berpolitik harus dilihat dalam perspektif relasi Islam dan politik sebagai sesuatu yang tidak dapat dipisahkan, dan secara konseptual bersifat polyinterpretable. Lepas dari perdebatan konseptual soal polyinterpretasi terhadap relasi antara Islam dan politik, seharusnya kyai tetap mengemban misi amar ma'ruf nahi munkar sebagai tugas yang paling utama seorang kyai dalam melakukan transformasi sosial. Di dalamnya menyangkut persoalan penegakan terhadap keadilan, penegakan hak-hak asasi manusia dan demokratisasi, serta perlawanan terhadap hegemoni kekuasaan dan segala macam bentuk tirani dan kezaliman. Dalam konteks ini, politik untuk membangun peradaban yang mampu menciptakan sebuah tatanan masyarakat yang mengedepankan nilai-nilai kemanusiaan sekaligus nilainilai ketuhanan, menonjolkan dimensi matrial sekaligus dimensi spiritual.50 Yakni, kyai Fawaid merupakan kyai politik yang berfungsi mendorong terlaksananya kemaslahatan segenap makhluk dengan memberi petunjuk jalan keselamatan di dunia dan akhirat. Sementara bagi ulama, pewaris Nabi Saw bahwa tugas ini hanya meliputi tugas lahiriah saja. ${ }^{51}$

Disinilah peran kyai bukan menjadi kepanjangan tangan penguasa yang korup, sebagaimana disebut oleh al-Ghazali sebagai ulama $s u^{\prime}$ (ulama buruk) yang sama dengan Dajjal untuk tujuan menyesatkan dan

${ }^{47}$ Abdul Munir Mulkan, Runtuhnya Mitos Politik Santri: Strategi Kebudayaan Islam (Yogyakarta: SIPRESS, 1984), .114.

48 Greg Fealy, "Kata Pengantar" dalam Ahmad Muhajir, Idham Chalid: Guru Politik Orang NU, (Yogyakarta: Pustaka Pesantren, 2007), ix-xii

${ }^{49}$ Muhyiddin Khatib dan Doni Ekasputra, Ijtihad, 149-150

50 Akram Dhiyauddin Umari, Masyarakat Madani: Tinjauan Historis Kehidupan Zaman Nabi (Jakarta: Gema Insani Pres, 1999), 33-34.

${ }^{51}$ KH. Sahal Mahfudz, Nuansa Fiqh Sosial (Yogyakarta: LKiS, 2012), 215-216. 
ilmunya dapat menyebabkan manusia pada kemaksiatan. ${ }^{52}$ Yakni, rasionalitas politik kyai yang didasarkan atas pertimbangan agama. Hal ini menunjukkan bahwa politik yang dilakukan kyai adalah politik moral, bukan politik pragmatis yang berorientasi materi. Dari perspektif habitus, terlihat bahwa perilaku politik kyai Fawaid sangat dipengaruhi oleh habitus pesantren yang mengajarkan ketulusan, kejujuran dan moral agama. Habituasi adalah menciptakan situasi dan kondisi (persistence life situation) tertentu yang ada kemungkinan peserta proses pembiasaan berperilaku sesuai dengan standar tertentu. Penciptaan ini diarahkan pada pembentukan karakter yang ideal melalui proses internalisasi dan pembiasaan dengan intervensi tertentu dalam tugas jabatan di tempat kerja yang harus dilakukannya. ${ }^{53}$ Dengan kata lain, perilaku politik kyai sesuai dengan nilai-nilai pesantren dan tidak terbawa arus habitus politik yang selalu pragmatis dan materialis. Dalam konteks politik, tipologi politik kyai Fawaid lebih dominan pada politik etis-moral dan bermartabat bukan politik menang-kalah yang dibungkus dengan warna abu-abu. Menang yang diperoleh dengan proses curang dan penuh tipuan, harus ditinggalkan. Sebaliknya, kalah dalam posisi benar dan jujur dan adil, maka harus dipertahankan. Inilah ijtihad politik kyai Fawaid untuk mengimplemetasikan kemaslahatan umat.

\section{Simpulan}

Paparan di atas dapat disimpulkan bahwa relasi santri dan kyai merupakan pola relasi emosional seperti feodal. Kyai dan memiliki tiga pilar, yaitu basis massa sebagai pola struktur sosial, basis ulama sebagai struktur kepemimpinan dan basis sistem budaya sebagai visi keilmuan. Sebagai konsekuensi ijtihad politik, ketiga pilar ini telah mengalami pergeseran akibat kyai masuk dalam politik praktis. Pergeseran tersebut menempatkan dari posisi pusat kyai sebagai guru spiritual menjadi posisi pinggiran sebagai politisi. Dalam hal ini, posisi kyai tetap ditaati jika menduduki posisi pusat, yaitu guru spiritual dan tidak akan ditaati jika posisinya bergeser menjadi pinggiran, yaitu kyai politisi. Tentu, hal ini menjadi dilematis sebagaimana dialami kyai Fawaid yang terlibat langsung dalam politik praktis. Keterlibatan kyai Fawaid merupakan ijihad politik bukan oportunis tetapi bentuk kepedulian untuk mengemban amar ma'ruf nahi munkar dalam transformasi sosial. Ijtihad

52 Al-Ghazali, Bidayah al-Hidayah (Libanon: Dar al-Kutub, 2011), 20

53 Muchlas Samani \& Hariyanto, Konsep dan Model Pendidikan Karakter (Bandung: PT Remaja Rosdakarya, 2001), 45.

$260 \mid$ JURNAL LISAN AL-HAL 
politik (fiqh siyasah) Kyai Fawaid sangat dipengaruhi oleh habituasi pesantren yang mendidik keikhlasan, etika-moral dan kejujuran. Habituasi disini adalah menciptkan situasi dan kondisi (persistence life situation) politik melalui proses internalisasi dan pembiasaan diri sesuai dengan nilai-nilai pesantren, tidak terbawa arus habituasi politik yang selalu pragmatis dan materialistik. Menurutnya menang dalam politik dengan penuh tipuan harus ditinggalkan dan kalah dengan cara yang benar harus dipertahankan.

\section{DAFTAR PUSTAKA}

Al-Attas, Naquib, Islam dan Sekularism. Bandung: Penerbit Pustaka, 1981. Al-Ghazali, Bidayah al-Hidayah. Libanon: Dar al-Kutub, 2011.

Arifin, Syamsul, “Kyai Fawaid As'ad: Kepribadian, Pemikiran dan Perilaku Politik, Jurnal Tanwirul Afkar, 2018.

Azra, Azyumardi, "Kata Pengantar" dalam Idris Thaha, Demokrasi Religius. Bandung: Mizan 2005.

Azra, Azyumardi, Kedatangan dan Penyebaran Islam di Asia Tenggara. Bandung: PT. Remaja Rosdakarya, 2000.

Dhofier, Zamakhsyari, Tradisi Pesantren. Jakarta: LP3ES, 1982

Dokumen ceramah KH. Fawaid pada Reuni Alumni 2008.

Dokumen Pesantren Salafiyah Syafi'iayah, Ceramah KH. Fawaid dengan Alumni Santri Sukorejo Situbondo di Aula Sukorejo Tahun 2004.

Fakhri, Majid, A History of Islamc Philosophy. New York: Columbia University Press, 1983.

Faruk, "Harga Sebuah Kepekaan dan Suara Lain", dalam Pradjarta Dirdjosanjoto, Memelihara Umat : Kyai Pesantren-Kyai Langgar di Jawa. Yogyakarta : LKiS, 1999.

Fawaid, KHR., "Tidak Mau Menukar Pesantren dengan Uang," Harian Bangsa Edisi 10, Januari 2004

Fealy, Greg, "Kata Pengantar" dalam Ahmad Muhajir, Idham Chalid: Guru Politik Orang NU. Yogyakarta: Pustaka Pesantren, 2007.

Ijtihad Politik Ulama: Sejarah NU 1952-1967. Yogyakarta: LKiS, 2009.

Ulama and Politic in Indonesia A History of Nahdlatul Ulama, Disertasi. Australia: Monash University, 1998.

Horikoshi, Hiroko, Kyai dan Perubahan Sosial. Jakarta: P3M, 1987.

Ibrahim, Anwar "Islam dan Pembentukan Masyarakat Madani", dalam Aswab Mahasin (eds.), Ruh Islam dalam Budaya Bangsa: Wacana Antar Agama dan Bangsa. Bandung: Mizan, 2000.

$$
\text { JURNAL LISAN AL-HAL } \mid 261
$$


Ismail, Faisal, Ideologi Hegemoni dan Otoritas Agama Wacana Ketegangan Kreatif Islam dan Pancasila. Yogyakarta : Tiara Wacana, 1999.

Kamil, S, Pemikiran Politik Islam Tematik, Agama dan Negara. Yogyakarta: Kencana Predana Media Group, 2013.

Ketahanan RI, Lembaga, Nilai-nilai Kebangsaan yang Bersumber dari UUD NRI Tahun 1945. Jakarta: Lembaga Ketahanan Nasional Republik Indonesia, 2017.

Khatib, Ach. Muhyiddin dan Doni Ekasaputra, Ijtihad Politik KHR. Ach. Fawaid As'ad. Situbondo: Ibrahimy Press, 2014.

Mahfudz, KH. Sahal, Nuansa Fiqh Sosial. Yogyakarta: LKiS, 2012.

Marijan, Kacung, Quo Vadis NU . Surabaya: Erlangga, 1992.

Mulkan, Abdul Munir, Runtuhnya Mitos Politik Santri: Strategi Kebudayaan Islam. Yogyakarta: SIPRESS, 1984.

Pondok Pesantren S2 Sukorejo, Biografi 3 Masyayih Sukorejo. Situbondo: P2S3, t. th.

Rais, M. Amin, Cakrawala Islam, antara Cita dan Fakta. Bandung: Mizan, 1996.

Salim, Abd. Muin, Konsepsi Kekuasaan Politik dalam al-Qur'an. Jakarta: Raja Grapindo Persada, 2002.

Samani, Muchlas \& Hariyanto, Konsep dan Model Pendidikan Karakter. Bandung: PT Remaja Rosdakarya, 2001.

Santoso, Riyadi, Pemerintahan Yang Bersih dan Masyarakat Madani. Yogyakarta: Tiara Wacana, 1998.

Sastroatmodjo, Sudijono, Perilaku Politik IKIP Semarang. Semarang: Semarang Press, 1995.

Sukarja, Ahmad, "Fikih siyasah" dalam Taufik Abdullah (eds.), Ensiklopedi Tematis Dunia Islam, Ajaran, II. Jakarta: Ichtiar Baru Van Hoeve, 2002.

Sukarja, Ahmad, "Fikih Siyasah" dalam Taufik Abdullah (eds.), Ensiklopedi Tematis Dunia Islam, Ajaran, II . Jakarta: Ichtiar Baru Van Hoeve, 2002.

Suprayago, Imam, Kyai dan Politik di Pedesaan: Suatu Kajian tentang Variasi dan bentuk Keterlibatan Politik Kyai, Desertasi. Surabaya: Universitas Airlangga. 1997.

Surbakti, Ramlan, Memahami Ilmu Politik. Jakarta. Gramedia Widya Sarana, 1992.

Taimiyah, Ibn, Al-Siyasah al-Syariah. Kairo: Dar al-Kutub al- Arabi, t. th.

Tilaar, H.A.R. Pendidikan Kebudayaan dan Masyarakat Madani Indonesia . Bandung: Remaja Rosda Karya, 1999.

$262 \mid$ JURNAL LISAN AL-HAL 
Umari, Akram Dhiyauddin, Masyarakat Madani: Tinjauan Historis Kehidupan Zaman Nabi. Jakarta: Gema Insani Pres, 1999.

Zainuddin, A. Rahman, "Ilmu Sejarah, Sosial dan Politik" dalam Taufik Abdullah (eds.), Ensiklopedi Tematis Dunia Islam, Pemikiran dan Peradaban. Yogyakarta: LkiS, 1999. 
"ljtihad Politik Kyai"

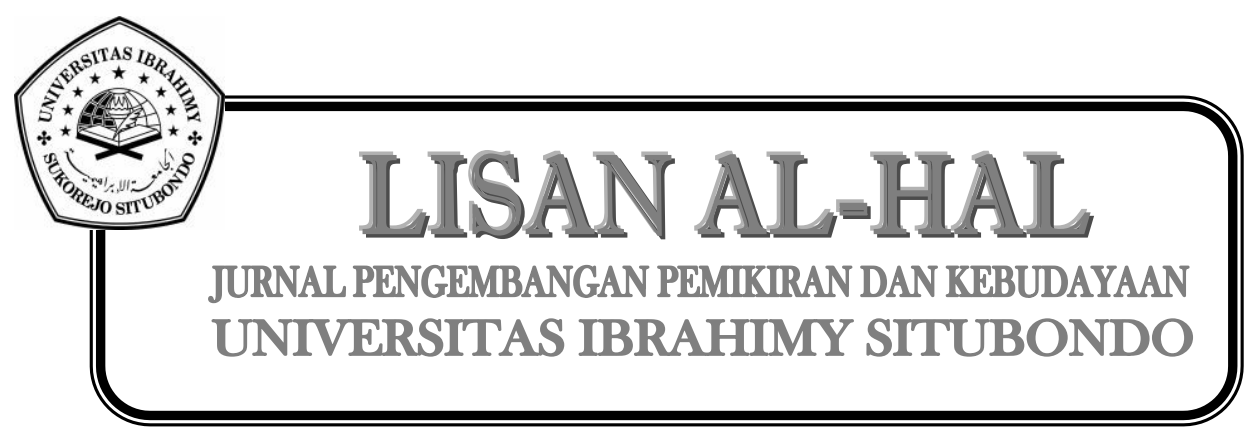

